EDNA FRASSON DE SOUZA MONTERO

https://orcid.org/0000-0003-1437-1219

UNIVERSIDADE FEDERAL DE SÃO PAULO

\title{
MISCONDUCT IN BRAZILIAN SCIENTIFIC JOURNALS IN THE FIELD OF HEALTH: PLAGIARISM AND AUTHORSHIP
}

https://doi.org/10.21452/procpc_09

Dissertação apresentada como parte dos requisitos para certificação no CSE Publication Certificate Program

São Paulo (SP)

2021 
ASSOCIAÇÃO BRASILEIRA DE EDITORES CIENTÍFICOS PROGRAMA PARA CAPACITAÇÃO EM PUBLICAÇÃO CIENTÍFICA

\section{EDNA FRASSON DE SOUZA MONTERO}

Universidade Federal de São Paulo

https://orcid.org/0000-0003-1437-1219

MISCONDUCT IN BRAZILIAN SCIENTIFIC JOURNALS IN THE FIELD OF HEALTH: PLAGIARISM AND AUTHORSHIP

São Paulo

2021 


\section{INTRODUCTION}

The fundamental principles of research integrity involve: reliability of research quality; honesty in research development and communication; respect for research actors; responsibility for research and, finally, awareness of responsibilities towards society ${ }^{1,2,3}$. The report Responsible Science: Ensuring the Integrity of the Research Process was guiding several countries, including Brazil, in the development of reports on good scientific practices ${ }^{4,5}$. In 2012, the Council of Science Editors updated details on the identification of research misconduct and guidelines for action ${ }^{6}$. This book was translated into Portuguese by the Associação Brasileira de Editores Científicos (ABEC Brasil) and is available at the website ${ }^{7}$.

In Brazil, since 2010 the Brazilian Meeting on Research Integrity, Science and Publication Ethics (BRISPE) has been organized with the idea of spreading the relevance of integrity in scientific production and publication. Last year, because of the pandemic the VI BRISPE was postponed to 2021. However, ABEC Brasil and members of BRISPE organized one webinar and a session at the ABEC Meeting Live 2020, highlighting the relevant role of scientific integrity ${ }^{8,9}$. In addition, ABEC Brasil promotes annual courses and conferences aimed at training editors, highlighting the importance of good editorial practices. Thus, Brazilian scientific journal editors are made aware of their responsibility in identifying misconduct and the investigation of notifications.

According to the Committee on Publication Ethics (COPE) recommendations, editors should support initiatives to reduce misconduct, ensuring the publication of suitable research. Respect for ethical principles in research, such as protecting research participants, ethical committee approval, and registering clinical research in databases, in addition to identifying plagiarism, improper image manipulation, falsification and data manufacturing, establishing authorship criteria, among others, are part of responsible editorial policy ${ }^{10,11}$.

Based on good practices in publication, this project aims to characterize how Brazilian scientific journals in the health field deal with two key aspects, the identification of plagiarism and the criteria for authorship. These aspects are relevant and allow an evaluation because the softwares for similarity detection and authorship criteria are available in different guidances ${ }^{11,12}$. Drawing this panorama may allow the elaboration of actions aimed at implementing best practices for the editors of journals in the health area.

The relevance of integrity in science and open science in scientific publication has been progressively established ${ }^{13}$. Researchers are academic evaluated based on publication and a progressive augmentation on misconduct has been observed ${ }^{14,15}$. Ethical conduct and reliable 
publication must be guaranteed by scientific editors. Thus, the purpose of this project is to draw the panorama of Brazilian scientific journals in the health area, indexed in the SciELO database, related to misconduct. The specific objectives are: 1) to identify misconduct related to the plagiarism and authorship criteria; 2) retractions related to the misconduct detected; 3) characterize editors' experience in detecting misconduct.

\section{METHODS}

The present study is primary, observational, cross-sectional and was carried out through a questionnaire sent to the editors of the 95 Brazilian health journals indexed in the SciELO database during 2020. The identity of the editors and journals were preserved when analyzing the data. The survey addressed the following items: scientific misconduct - what is the frequency of detection of misconduct, the editor's knowledge of the types, rules and sanctions related to the authorship in the publication; if similarity detection software is used; if they establish an acceptable percentual of similarity score; which software is used. Finally, some questions about the editor's experience in managing misconduct. Data is reported through a descriptive statistical analysis, establishing frequency and types of correlation detected.

\section{RESULTS AND DISCUSSION}

The survey was sent to the editors of the 95 Brazilian health journals, of which 23 responded, corresponding to $24.5 \%$ of the invited scientific journals. More returns were expected; however, the sample becomes representative since the responses were quite convergent.

\section{Similarity (prepublication)}

In the responses about similarity detection system used by the editors, it was observed that only two journals do not use any kind of similarity detection software. On the other hand, $17(80.9 \%)$ out of 21 journals use iThenticate, one (4.8\%) uses Turnitin, and other $(4.8 \%)$ uses Plagius professional, two $(9.5 \%)$ out of 21 use free softwares, CopySpider and Noplag. All editors that use similarity systems also apply filters, distributed as follows: 19\% apply several filters, including references, citations, methods and abstracts; 24\% filter references and citations, methods or abstracts; $28 \%$ filter references and abstracts or citations or number of words; $24 \%$ filter only references and $5 \%$ only citations. 
It is interesting to observe that the use of payed software is common among editors of the health area, showing the preoccupation in detecting plagiarism. Also, editors care about authors, asking adequacy instead of rejecting the manuscript directly.

When identifying similarity, the majority asks the authors to make adjustments (70\%), even so, manuscripts can be denied. Some editors reject the manuscript without requesting adjustments $(30 \%)$. Regarding the reference index, the editors consider more important to assess in which part of the manuscript the similarity occurs than the level of similarity. Therefore, the reference index is considered relevant if it exceeds $30 \%$, even when applying filters. Figure 1 shows a general information about the similarity aspects.

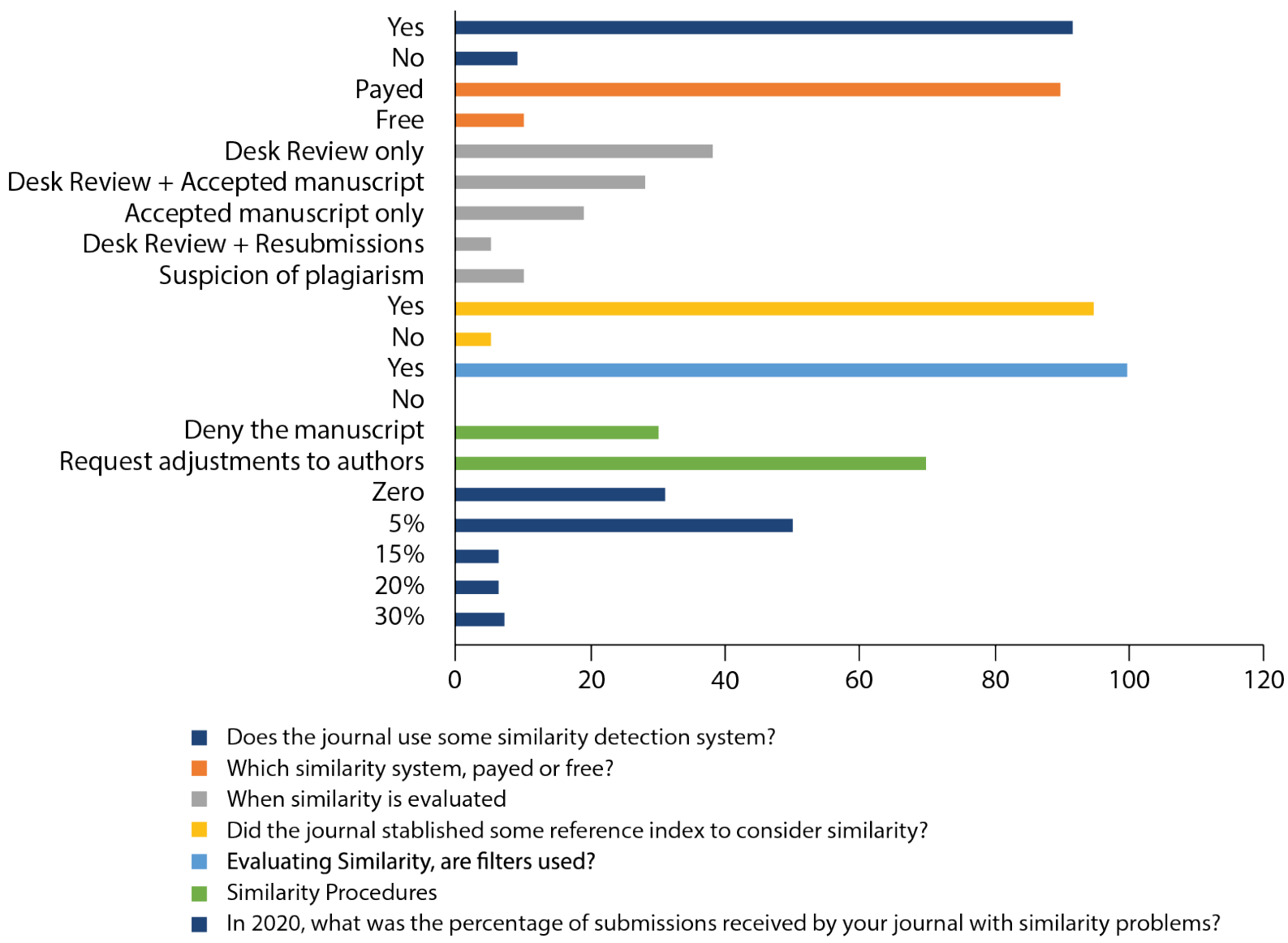

Figure 1. Similarity aspects.

Another relevant point is the moment of submission to the software of similarity detection. The vast majority go through the system during the desk review and in accepted manuscripts. Two important moments, because if some plagiarism is detected, the reviewer is spared of a fruitless evaluation. 


\section{Authorship (prepublication)}

Most editors do not establish a limit in the number of authors (70\%), but they use some authorship attribution system (74\%). As for undue authorship, almost all editors ask the authors for adequacy or justification (96\%). Only one editor rejects the manuscript under suspicion of improper authorship without asking for explanations.

Regarding the authorship attribution system, $74 \%$ of the editors use some system, but there is a preference for the International Committee of Medical Journal Editors (ICMJE), maybe because they are journals in the health area closely related to the ICMJE (Table 1).

Table 1. Data about authorship.

\begin{tabular}{|c|c|c|c|c|c|c|c|c|c|}
\hline \multicolumn{4}{|c|}{$\begin{array}{c}\text { Does the journal determine a limit } \\
\text { of authors per manuscript in its } \\
\text { editorial policy? }\end{array}$} & \multicolumn{4}{|c|}{$\begin{array}{l}\text { Does the journal use any } \\
\text { authorship attribution system? }\end{array}$} & \multicolumn{2}{|c|}{$\begin{array}{l}\text { If undue authorship is found during } \\
\text { the manuscript evaluation process, } \\
\text { what is the journal's attitude? }\end{array}$} \\
\hline \multicolumn{3}{|c|}{ Yes } & No & \multicolumn{3}{|c|}{ Yes } & No & $\begin{array}{l}\text { Reject the } \\
\text { manuscript }\end{array}$ & $\begin{array}{l}\text { Request } \\
\text { justification/adequacy to } \\
\text { authors for re-evaluating } \\
\text { the manuscript }\end{array}$ \\
\hline \multicolumn{3}{|c|}{$30 \%(n=7)$} & \multirow{3}{*}{$\begin{array}{c}70 \% \\
(n=16)\end{array}$} & \multicolumn{3}{|c|}{$74 \%(n=17)$} & \multirow{3}{*}{$\begin{array}{c}26 \% \\
(\mathrm{n}=6)\end{array}$} & \multirow{3}{*}{$\begin{array}{c}17 \% \\
(\mathrm{n}=4)\end{array}$} & \multirow{3}{*}{$\begin{array}{c}96 \% \\
(\mathrm{n}=22)\end{array}$} \\
\hline$<8$ & $<6$ & $\begin{array}{l}\text { Depends } \\
\text { on the } \\
\text { article }\end{array}$ & & ICMJE & CRediT & ORCID & & & \\
\hline $43 \%$ & $29 \%$ & $28 \%$ & & $77 \%$ & $12 \%$ & $11 \%$ & & & \\
\hline
\end{tabular}

There is an important educational role of the editor towards reviewers and authors, becoming essential in the process of developing scientific integrity awareness. The consequences of misconduct in the publication go beyond retraction. Fraudulent research implies financial and social loss for science and society, in addition to compromising individual reputation. Observing the responses of the editors, one can see the concern in detecting plagiarism, but also in discussing with the authors and the editorial board, thus highlighting the educational process.

\section{Retractions (post publication)}

Editors reported that misconduct is rarely observed (100\%). It may be due to the lack of active research or the tools are not sufficient to detect other forms of misconduct or even improper authorship. Plagiarism is easier to verify because of the software available in publishing and academic markets today. Data are detailed in the Tables 2 and 3. 
Table 2. Reports of misconduct received by the journals.

\begin{tabular}{cccc}
\hline & \multicolumn{3}{c}{ Has the journal ever received any of these misconduct reports? } \\
\hline Responses & $\begin{array}{c}\text { Plagiarism } \\
\%(\mathbf{n})\end{array}$ & $\begin{array}{c}\text { Undue authorship } \\
\%(\mathbf{n})\end{array}$ & $\begin{array}{c}\text { Others } \\
\text { (data falsification, image manipulation, etc.) \% (n) }\end{array}$ \\
\hline Yes & $26(6)$ & $35(8)$ & $17(4)$ \\
\hline No & $74(17)$ & $65(15)$ & $83(19)$ \\
\hline
\end{tabular}

Table 3. Retractions due to misconduct.

\begin{tabular}{cccc}
\hline & \multicolumn{3}{c}{ Did the journal make any of these retractions? } \\
\hline Responses & $\begin{array}{c}\text { Plagiarism } \\
\%(n)\end{array}$ & $\begin{array}{c}\text { Undue authorship } \\
\%(n)\end{array}$ & $\begin{array}{c}\text { Others } \\
\text { (data falsification, image manipulation, etc.) \% (n) }\end{array}$ \\
\hline Yes & $13(3)$ & $13(3)$ & $17(4)$ \\
\hline No & $87(20)$ & $87(20)$ & $83(19)$ \\
\hline
\end{tabular}

The editors answered that they do something when receive notification of misconduct, as can be observed in Fig. 2. The authors were consulted in $61 \%$ of the cases and $52 \%$ of the cases required investigation by the editorial board. Retraction of articles was made in $22 \%$ of cases, and the author's institution was reported in $13 \%$.

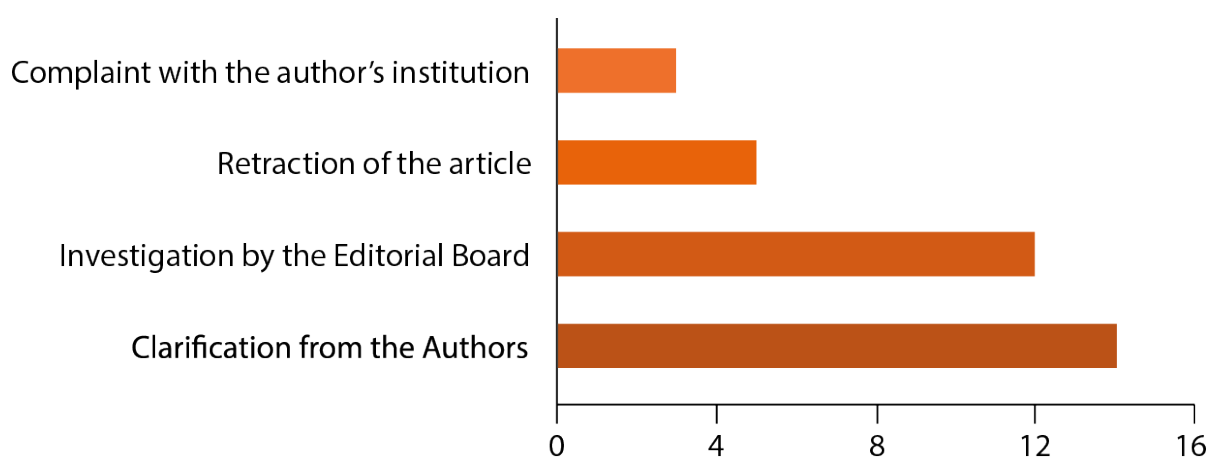

Figure 2. Journal position in the case of reported misconduct.

The number of publications in Brazil has been increasing in an accelerated way, stimulated by the academic prestigious and survival. Scientific publication is the main indicator of academic productivity, even in the graduate program evaluation. Thus, scientific journals and editors are part of a team that must work to avoid research misconduct. In a recent study, it was observed that most of the retracted health and life sciences publications in Brazil were 
retracted due to research misconduct. More investigations are needed to comprehend the underlying factors of research misconduct and its increasing manifestation ${ }^{14,15}$.

However, these data deserve to be deeply investigated and clarified, since Brazilian health journals receive many articles from other countries, which also have problems related to misconduct, such as Iran, Iraq, Turkey and China ${ }^{16,17}$. Agreeing with the Chinese authors that investigate retracted articles from China, integrity education and severe sanctions is fundamental, but also reinforce the transparency in retraction by the scientific editors ${ }^{17}$.

According to these data, there is a sequence of attitudes the editors take when facing misconduct. First, ask the authors to clarify the possible misconduct, if the doubt persists, the investigation by the editorial committee will be carried out. This reflects the care with science, but also with the authors, so that an undue accusation can be avoided.

\section{Other misconduct (pre and post publication)}

These data show that clinical research should be a focus for the graduate programs, preparing researchers when they are developing their projects. In fact, the absence of established standards for clinical research and the lack of registration in databases, which reflects care for the research participant and transparency in data collection, must be addressed during the development of the research project. Misconduct in the publication reflects a failure in the training of the researcher, sometimes more than bad character (Fig. 3). Once more, educational role of the editor is important to reach good practices in publication, as well as in research.

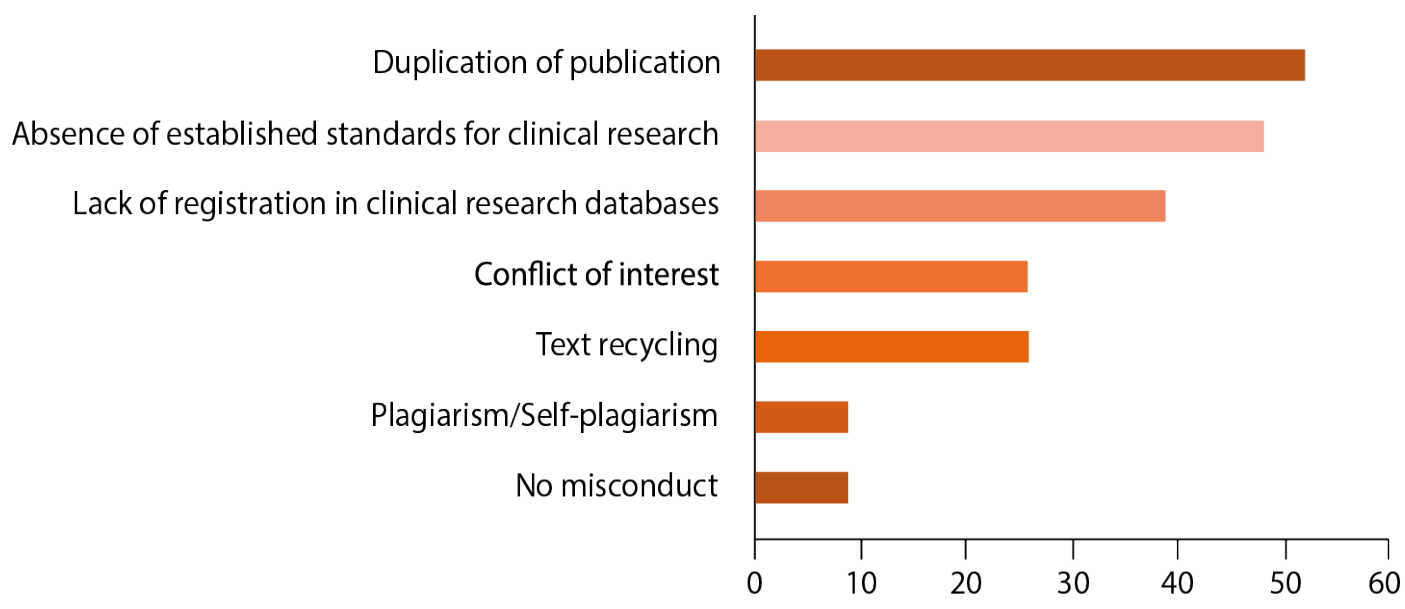

Figure 3. Misconduct detected during the evaluation of the manuscript or in the article already published (\%). 
Nowadays, softwares to detect similarity are good instruments that allow verification of plagiarism in the manuscript professionally, with accuracy. However, the scientific content evaluation is an important step, complementary to the similarity index (Fig. 4).

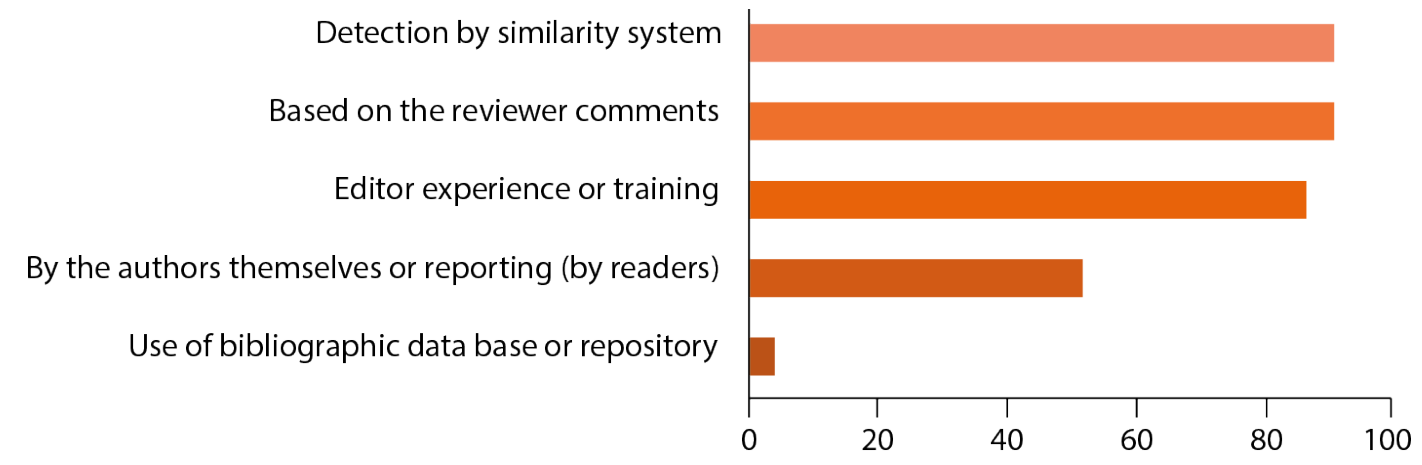

Figure 4. How can the editor detect misconduct? (\%).

This question addressed the relevance of different instances to teach and train editors about misconduct and best editorial practices (Fig. 5). On this way, editors help in the education of the researchers during the publication step, which will reflect in good practices in research.

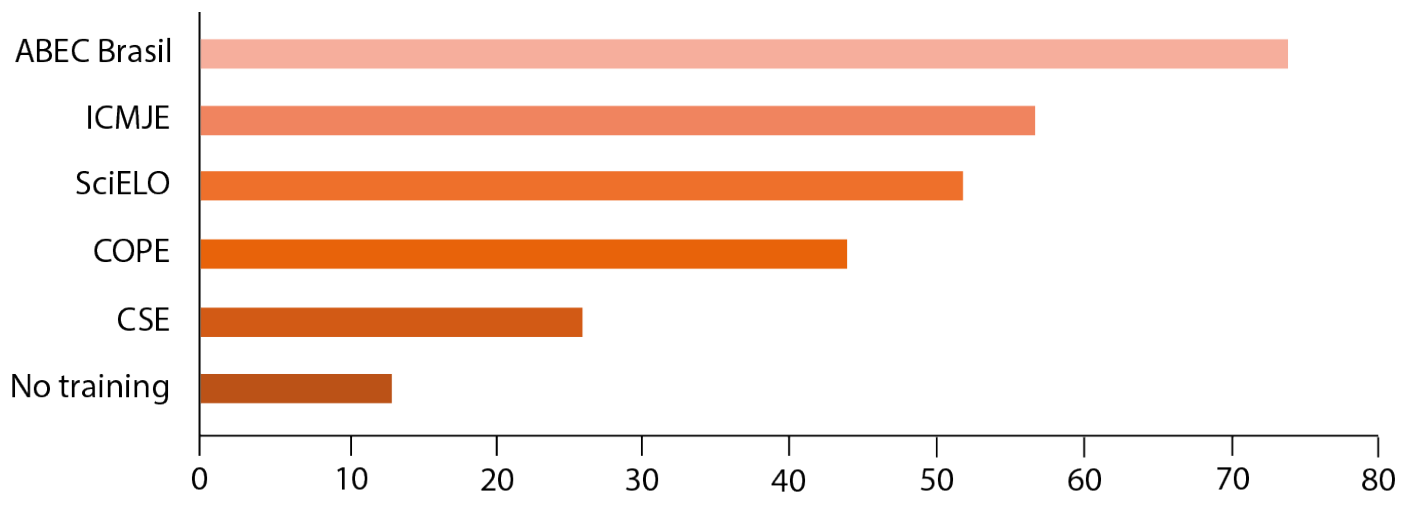

Figure 5. What institutions can the editor use for training related to detection and actions in the face of misconduct? (\%).

\section{FINAL CONSIDERATIONS}

Editors and researchers must be aware that researchers and society in general can disclose the results of reliable and transparent research. Committee on Publication Ethics recommends that, when identifying misconduct, the editor should initiate appropriate detailed procedures informing institutions and funders, and may choose to publish the concern, pending on the results of these procedures. There may be circumstances in which no misconduct is 
proven, but an exchange of letters with the editor can be posted to highlight issues of debate for readers.

There are two points to be highlighted identified from this research: the lack of training of researchers, the authors, in the development of clinical research, considering the standards related to research ethics, whether it concerns registration in clinical research databases, or in the submission and approval of the project, before it begins, by a research ethics committee for the adequate protection of the research participant, as well as in the quality of the knowledge generated.

Another relevant point is the importance of training the editor, professionalizing his performance in view of the great responsibility related to the publication of science, of the knowledge generated. In this item, ABEC Brasil has had a fundamental role with editors from different areas of knowledge, offering courses and meetings in which the formation of the editor is promoted. In addition, in association with the Council of Science Editors (CSE), it has offered the publisher's certification program, which the author of this research considers very valuable, providing the opportunity for the professionalization of one of the important actors in the scientific communication chain and the publication of the knowledge generated among researchers. However, certified publishers are rare, and the publisher's experience is also used to detect misconduct. This study reinforces that scientific education, from the generation of knowledge to its publication, is the central core of good practices in science, both as a researcher and as a reviewer, as well as an editor.

Based on these results, recommendations will be made to the editors about actions that should be implemented for best editorial practices related to plagiarism and authorship criteria. These recommendations will be forwarded and, possibly, worked with the editors of the studied journals.

\section{REFERENCES}

1. Gross C. Scientific Misconduct. Annu Rev Psychol. 2016;67:693-711. https://doi.org/10.1146/annurev-psych-122414-033437

2. Mayden KD. Plagiarism's Poison: Avoiding Scientific Misconduct. J Adv Pract Oncol. 2015;6(1):77-80. https://doi.org/10.6004/jadpro.2015.6.1.9 
3. National Academy of Sciences, National Academy of Engineering, and Institute of Medicine. Responsible Science: Ensuring the Integrity of the Research Process: Volume I. Washington: The National Academies Press; 1992. https://doi.org/10.17226/1864

4. National Academy of Sciences, National Academy of Engineering, and Institute of Medicine. Responsible Science: Ensuring the Integrity of the Research Process: Volume II. Washington: The National Academies Press; 1993. https://doi.org/10.17226/2091

5. Fundação de Amparo à Pesquisa do Estado de São Paulo (FAPESP). Código de boas práticas científicas. São Paulo: FAPESP; 2014. [cited 27 Mar. 2021]. Available at: https://fapesp.br/boaspraticas/FAPESP-Codigo_de_Boas_Praticas_Cientificas_2014.pdf

6. Editorial Policy Committee. CSE's White Paper on Promoting Integrity in Scientific Journal Publications; 2012 Update. Wheat Ridge: Council of Science Editors; 2012. [cited 27 Mar. 2021]. Available at: http://www.councilscienceeditors.org/wpcontent/uploads/entire_whitepaper.pdf

7. Associação Brasileira de Editores Científicos (ABEC Brasil). Diretrizes do CSE para Promover Integridade em Publicações de Periódicos Científicos Atualização de 2012. São Paulo: ABEC Brasil; 2017. [cited 27 Mar. 2021]. Available at: https://www.abecbrasil.org.br/arquivos/whitepaper_CSE.pdf

8. Vasconcelos S, Vieyra AR. Webinar dez anos de transformações: uma perspectiva sobre integridade científica no Brasil a partir do BRISPE - Brazilian Meeting on Research Integrity, Science and Publication Ethics. Webinar ABEC Brasil; 2020. [cited 27 Mar. 2021]. Available at: https://youtu.be/PNAgkXYKLbU

9. Werlang E, Carlim PE, Rode SM. Desafios e perspectivas da editoria científica memórias críticas do ABEC Meeting Live 2020. Botucatu: ABEC Brasil; 2021. [cited 27 Mar. 2021]. Available at: https://www.abecbrasil.org.br/arquivos/ABEC_Meeting_Live_2020_Resenhas_Criticas.pdf 10. Committee on Publication Ethics (COPE). COPE Best Practice Guidelines for Journal Editors [Internet]. [cited 27 Mar. 2021]. Available at: https://publicationethics.org/files/u2/Best_Practice.pdf 
11. International Committee of Medical Journal Editors (ICMJE). Defining the Role of Authors and Contributors [Internet]. [cited 27 Mar. 2021]. Available at: http://www.icmje.org/recommendations/browse/roles-and-responsibilities/defining-the-roleof-authors-and-contributors.html

12. Committee on Publication Ethics (COPE). Allegations of misconduct [Internet]. [cited 27 Mar. 2021]. Available at: https://publicationethics.org/misconduct

13. Nassi-Calò L. Challenges for sustainability of the open access model: Brazilian health journals. Rev Latino-Am Enfermagem. 2016;24:e2827. https://doi.org/10.1590/15188345.0000 .2827

14. Pádua GCC, Guilhem D. Integridade científica e pesquisa em saúde no Brasil: revisão da literatura. Rev Bioét. 2015;23(1):124-38. https://doi.org/10.1590/1983-80422015231053

15. Stavale R, Ferreira GI, Galvão JAM, Zicker F, Novaes MRCG, Oliveira CMd, et al. Research misconduct in health and life sciences research: A systematic review of retracted literature from Brazilian institutions. PLoS ONE. 2019;14(4):e0214272. https://doi.org/10.1371/journal.pone.0214272

16. Kamali N, Abadi ATB, Rahimi F. Plagiarism, Fake Peer-Review, and Duplication: Predominant Reasons Underlying Retractions of Iran-Affiliated Scientific Papers. Sci Eng Ethics. 2020;26(6):3455-63. https://doi.org/10.1007/s11948-020-00274-6

17. Lei L, Zhang Y. Lack of Improvement in Scientific Integrity: An Analysis of WoS Retractions by Chinese Researchers (1997-2016). Sci Eng Ethics. 2018;24(5):1409-20. https://doi.org/10.1007/s11948-017-9962-7 